\title{
Locally Advanced Neuroendocrine Carcinoma
}

National Cancer Institute

\section{Source}

National Cancer Institute. Locally Advanced Neuroendocrine Carcinoma. NCI Thesaurus.

Code C158909.

A neuroendocrine carcinoma that has spread from its original site of growth to nearby tissues or lymph nodes. 